\title{
Effect of Gamma Irradiation on Suruhan (Peperomia pellucida (L.) Kunth) Herb Powder
}

\author{
Mubarika Sekarsari Yusuf, Intan Wulandari, Lili Amelia, Katrin, Arikadia Noviani, Rissyelly, Abdul Mun'im*
}

Mubarika Sekarsari Yusuf, Intan Wulandari, Lili Amelia, Katrin, Arikadia Noviani, Rissyelly, Abdul Mun'im*

Department of PharmacognosyPhytochemistry, Faculty of Pharmacy, Kampus Baru UI Depok, Jawa Barat, 16424, Indonesia

\section{Correspondence}

\section{Abdul Mun'im}

Department of Pharmacognosy-Phytochemistry, Faculty of Pharmacy, Kampus Baru UI Depok,

Jawa Barat, 16424, Indonesia

Phone: +62 217270031

Email: munim@farmasi.ui.ac.id

\section{History}

- Submission Date: 21-12-2016;

- Review completed: 05-01-2017;

- Accepted Date: 11-01-2017.

DOI : 10.5530/pj.2017.2.40

Article Available online

http://www.phcogj.com/v9/i2

\section{Copyright}

(C) 2017 Phcog.Net. This is an openaccess article distributed under the terms of the Creative Commons Attribution 4.0 International license.

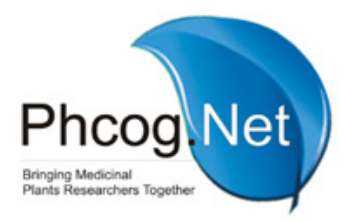

\begin{abstract}
Introduction: Peperomia pellucida (L.) Kunth is known as a raw material for herbal medicine; Preservation of herbs powder by gamma irradiation is reported to be able to keep products free from contamination. Methods: This study aims to evaluate the effect of gamma irradiation $(0 ; 2.5 ; 5 ; 7.5$; and $10 \mathrm{kGy})$ on the ACE inhibitory activity (ACE Kit - WST test kit method), antioxidant activity (DPPH radical scavenging method), total phenolic content (colorimetric method using Folin-Ciocalteu reagent), total flavonoid content (colorimetric method using $\mathrm{AICl} 3$ and sodium acetate), and TLC profiling (silica gel $\mathrm{F}_{254}$ as the stationary phase and dichlormethane:methanol [92:8] as the mobile phase) of suruhan herb powder. Results: Results showed that the 2.5 kGy irradiation dose gave the smallest alteration in ACE inhibitory activity compared to others irradiated doses. Furthermore, the 5 and 7.5 kGy dose didn't cause significant change ( $p>0.05$ ) on antioxidant activity, total phenolic content, and total flavonoid content. Antioxidant activity was found to correlate with the total phenolic content but not with the total flavonoid content. Conclusion: Based on these finding, it is concluded that gamma irradiation can be used as a preservation method for P. pellucida herb powder.
\end{abstract}

Key words: Angiotensin converting enzyme, Antioxidant activity, Total flavonoid, Total phenolic, Peperomia pellucida.

\section{INTRODUCTION}

Peperomia pellucida L. Kunth or suruhan is easily found in Indonesia and has the potential of being a herb medicine. Various studies have proven that this plant has an antioxidant and hypotensive effect. ${ }^{1,2}$ It's known that about $70-95 \%$ of society in developing nations use herbal medicine as their primary medication. ${ }^{3}$ Nonetheless, contamination during the processing and storage stages can shorten the shelf life of those herbal materials and even cause danger to consumers if they are contaminated by pathogenic bacteria such as Salmonella and Staphylococcus. ${ }^{4}$ Even though other ways of decontamination are available, gamma irradiation is preferred due it's low temperature during a process, high penetration capability, and it also doesn't produce hazardous waste. ${ }^{5}$ The aim of this study was to analyze and evaluate the effect of gamma irradiation on the chemical constituents and bioactivity of suruhan herb powder.

\section{MATERIALS AND METHODS}

\section{Materials}

Dry herb of Peperomia pellucida L. Kunth was collected from BALITRO ( Bogor, West Java), Angiotensin-converting enzyme (ACE) Kit-WST test kit was purchased from Dojindo Laboratories, Japan, Quercetin, 2,2-diphenyl-1-picrylhydrazyl, sodium acetate and Folin-Ciocalteu reagent (Sigma-Aldrich), gallic acid, sodium carbonate and aluminium chloride, tol- uene, dichloromethane and methanol (Merck), and captopril (Kimia Farma Ltd, Indonesia).

\section{Sample Preparation}

Dried samples from Balitro (Balai Penelitian Tanaman Obat dan Aromatika), Bogor, West Java, were sorted out to separate them from pollutants, blended, then were put through a 25 mesh sieve.

\section{Water Determination}

Determination of moisture content was done with toluene distillation method.

\section{Gamma irradiation}

The sample powders $(50 \mathrm{~g})$ were packed with polyethylene plastic bags and irradiated using gamma with cobalt-60 as the radiation source. The dose rate was $5.79 \mathrm{kGy}$ per hour with dose level of $2.5 ; 5 ; 7.5$ and $10 \mathrm{kGy}$. At each dose level, three bags of $50 \mathrm{~g}$ of suruhan herb powder were irradiated. Irradiation was conducted at National Nuclear Energi Agency of Indonesia.

\section{Total Plate Count (TPC) TPC was done using dilution method.}

\section{Plant extraction}

Sample powder was extracted after irradiation process by reflux using 70\% ethanol (1:10) for 45 minutes and repeated 4 cycles. All filtrates were combined and evaporator and was concentrated and then dried using rotary vacuum evaporator vacuum oven at $40^{\circ} \mathrm{C}$. 


\section{Free radical scavenging assay with DPPH}

Various concentration of samples was prepared by dissolving the extract using methanol. About $1 \mathrm{~mL}$ of each concentration was put in a test tube, added $1 \mathrm{~mL}$ of $100 \mathrm{ppm}$ DPPH solution and $2 \mathrm{~mL}$ of methanol pa. The mixture was vortexed and incubated for 30 minutes at $37^{\circ} \mathrm{C}$. The absorbance of each concentration was measured with Uv-Vis spectrophotometer at $515 \mathrm{~nm}$. Quercetin was used as the standard.

\section{ACE inhibitory activity assay}

ACE inhibitory activity assay was done following the procedure from the ACE Kit - WST test kit from Dojindo Laboratories, Japan. Captopril was used as the standard.

\section{Determination of Total Phenolic Content}

Total phenolic content was determined using the Folin-Ciocalteu colorimetric methods. ${ }^{6}$ Different concentration of gallic acid (30-80 ppm) and sample $(3000 \mathrm{ppm})$ were dissolved in methanol. About $200 \mu \mathrm{L}$ of each concentration was put into test tube, and $1.5 \mathrm{~mL}$ Folin-Ciocalteu was added. All test tubes were incubated in a dark place at room temperature for 5 minutes. Then $1.5 \mathrm{~mL} \mathrm{Na}_{2} \mathrm{CO}_{3}$ was added to each test tube and incubated for 60 minutes in a dark place at room temperature. The absorbance of each concentration was measured using UV-Vis spectrophotometer at $740 \mathrm{~nm}$.

\section{Determination of Total Flavonoid Content}

Determination of total flavonoid content was done using aluminium chloride colorimetric methods. ${ }^{7,8}$ Various concentration of quercetin (20 - $120 \mathrm{ppm}$ ) and sample (3000 ppm) were dissolved in methanol. About $0.5 \mathrm{~mL}$ of each concentration was taken in a test tube, added $1.5 \mathrm{~mL}$ methanol, $0.1 \mathrm{~mL}$ of $10 \%$ aluminium chloride, $0.1 \mathrm{~mL}$ sodium acetate $1 \mathrm{M}$ and $2.8 \mathrm{~mL}$ distillate water into each test tube. Then, the test tubes were incubated at room temperature for 30 minutes. The absorbance of each concentration was measured by Uv-Vis Spectrophotometer at 434 nm.

\section{Thin Layer Chromatography Profile}

TLC profiles were performed using silica gel $60 \mathrm{~F}_{254}$ and dichlormethane: methanol (92:8). Ethanolic as eluent extracts were made at 10000 ppm and were spotted on the TLC plate for elusion. TLC was analyzed qualitatively under UV light of $254 \mathrm{~nm}$ and $366 \mathrm{~nm}$, also by qualitative densitometry using TLC Scanner 3 with Camag Wincats software.

\section{Statistical Analysis}

Data was analyzed using one-way ANOVA and a significant difference was determined by the Tukey test $(\alpha=0.05)$. Correlation between antioxidant activity, total phenolic compound, and total flavonoid compound was analyzed using Spearman test.

\section{RESULTS}

\section{Water Determination}

The moisture content of suruhan herb powders obtained were $7.40 \%$ and 7.96\%. This result is higher than the previous study. ${ }^{9}$ According to 'Peraturan Kepala BPOM Republik Indonesia' number 12; 2014 about quality requirements of traditional medicine states that moisture content of simplisia powders were less than $10 \%$.

\section{Total Plate Count (TPC)}

Table 1 showed effect of gamma-irradiation on TPC. At dose of $2.5 \mathrm{kGy}$ can reduce $\mathrm{TPC}<10$ colony/ gram.

\section{Extraction Yields}

Extraction yield of non-irradiated and irradiated simplisia herbs ranged from $21.16-24.86 \%$.

\section{Free Radical Scavenging Assay with DPPH}

The results show that there is no significant difference $(\mathrm{p}>0,05)$ free radical scavenging activity of samples after gamma irradiation at dose 2.5 $\mathrm{kGy}, 5 \mathrm{kGy}$, and $7.5 \mathrm{kGy}$ if was compared to the nonirradiated sample. Similar results on radical scavenging activity were reported for Korean herbal medicine after irradiation. ${ }^{14}$ However, there's a significant decrease $(\mathrm{p}<0,05)$ on radical scavenging activity of Peperomia pellucida after irradiation at $10 \mathrm{kGy}$ (Table 2).

ACE Inhibitory Activity Assay

ACE inhibitory activity of captopril at ppm was $34.42 \%$ and all ethanol extracts were measured at $100 \mathrm{ppm}$, giving results as shown in Table 3 .

\section{Total Phenolic Content}

The measurement of total phenolic content was done using colorimetric Folin-Ciocalteu method. TPC of irradiated and non-irradiated Peperomia pellucida shown in Table 4.

\section{Total Flavonoid Content}

Total flavonoid content was measured using a colorimetric method with $\mathrm{AlCl}_{3}$ and sodium acetate as reagent. Total flavonoid content non-irradiated and after irradiated at 2.5; 5; 7.5 and $10 \mathrm{kGy}$ shown in Table 5.

\begin{tabular}{ccc}
\multicolumn{4}{c}{ Table 1: Effect of irradiation on TPC of suruhan herb powder } \\
\hline No & Irradiation dose (kGy) & TPC (Colony/g) \\
\hline 1 & 0 & $296 \times 10^{6}$ \\
2 & 2.5 & $<10$ \\
3 & 5 & $<10$ \\
4 & 7.5 & $<10$ \\
5 & 10 & $<10$ \\
\hline
\end{tabular}

Table 2: Antioxidant activity of non-irradiated and irradiated Peperomia pellucida herb powders

\begin{tabular}{cc}
\hline Dose $(\mathrm{kGy})$ & $\mathrm{EC}_{50} \pm \mathrm{SD}$ \\
\hline 0 & $210.85 \pm 5.98$ \\
2.5 & $214.60 \pm 8.021$ \\
5 & $200.83 \pm 5.21$ \\
7.5 & $199.67 \pm 5.76$ \\
10 & $279.31 \pm 8.48^{\star}$ \\
\hline
\end{tabular}

Each value is expressed as mean \pm standard deviation $(n=3)$

* significantly different $(\mathrm{p}<0.05)$ compare to $0 \mathrm{kGy}$

Table 3: ACE inhibitory activity of ethanol extracts of suruhan herb powder after irradiation

\begin{tabular}{cc}
\hline Irradiation dose (kGy) & Inhibitory activity $(\%) \mathbf{n = 3}$ \\
\hline 0 & 76.20 \\
2.5 & 76.07 \\
5 & 73.73 \\
7.5 & 73.06 \\
10 & 74.79 \\
\hline
\end{tabular}


Table 4: Total phenolic content of irradiated and non-irradiated suruhan herb powder

\begin{tabular}{cc}
\hline Irradiation dose (kGy) & $\begin{array}{c}\text { Phenolic content (mg GAE/g extract) } \\
\pm \text { SD }\end{array}$ \\
\hline 0 & $21.10 \pm 0.11$ \\
2.5 & $18.17 \pm 0.28^{*}$ \\
5 & $21.24 \pm 0.13$ \\
7.5 & $21.53 \pm 0.20$ \\
10 & $19.45 \pm 0.25^{*}$ \\
\hline
\end{tabular}

Each value is expressed as mean \pm standard deviation $(n=3)$

* significantly different $(\mathrm{p}<0,05)$ compare to $0 \mathrm{kGy}$

Table 5: Total Flavonoid Content

\begin{tabular}{cc}
\hline Irradion dose $(\mathrm{kGy})$ & Total flavonoid content $(\mathrm{mg} \mathrm{QE} / \mathrm{g}$ extract) \\
\hline 0 & $12.36 \pm 0.40$ \\
2,5 & $7.05 \pm 0.86^{*}$ \\
5 & $11.65 \pm 0,57$ \\
7,5 & $13.684 \pm 0.12$ \\
10 & $8.586 \pm 0.47^{*}$ \\
\hline
\end{tabular}

Each value is expressed as mean \pm standard deviation $(n=3)$

* significantly different $(\mathrm{p}<0,05)$ compare to $0 \mathrm{kGy}$

\section{Thin Layer Chromatography (TLC) Profile}

TLC profiles of all samples under $254 \mathrm{~nm}$ and $366 \mathrm{~nm}$ were similarly profile. Under $254 \mathrm{~nm}$, the non-irradiated sample gave 11 peaks which were also found in the irradiated samples. Peaks were also found at $R_{f}$ 0.18 and 0.67 only from the $5 \mathrm{kGy}$ irradiated sample. Under $366 \mathrm{~nm}$, the non-irradiated sample gave 12 peaks which were also found in the irradiated samples. Another peak was also found between Rf 0.62 and 0.64 only from the $5 \mathrm{kGy}$ irradiated sample. After spraying the TLC plate with $\mathrm{AlCl}_{3}$ solution, 10 spots demonstrated the change color into yellowish and greenish (Figure 1).

\section{Correlation Analysis}

Statistical analysis shows that there's a negative correlation between antioxidant activity with total phenolic content but there's no correlation between antioxidant activity with total flavonoid content. These results are supported by previous research which states that there's correlation between antioxidant activity with total phenolic content of Peperomia pellucida but have no correlation with flavonoid content. ${ }^{32}$ Total phenolic content and total flavonoid content shows a positive correlation.

\section{DISCUSSION}

\section{Total Plate Count (TPC)}

TPC of the herb powder showed a decrease of microbial growth in all irradiated samples where this result was in accordance with "Peraturan Kepala BPOM” number 12; 2014' about quality requirements of traditional medicine. Furthermore, based on 'Peraturan Menteri Kesehatan Republik Indonesia No. 701/MENKES/PER/VIII/2009' about foods irradiation, the maximum dose of dried herbs is $1 \mathrm{kGy}$ to eliminate insects, and $10 \mathrm{kGy}$ to eliminate pathogenic microorganisms. Gamma irradiation can kill bacteria by destroying DNA of bacteria. ${ }^{5}$

\section{Extraction Yields}

Ethanol was used because of its non-toxic characteristics and is permitted to be used by the Department of Health of the Republic of Indone-

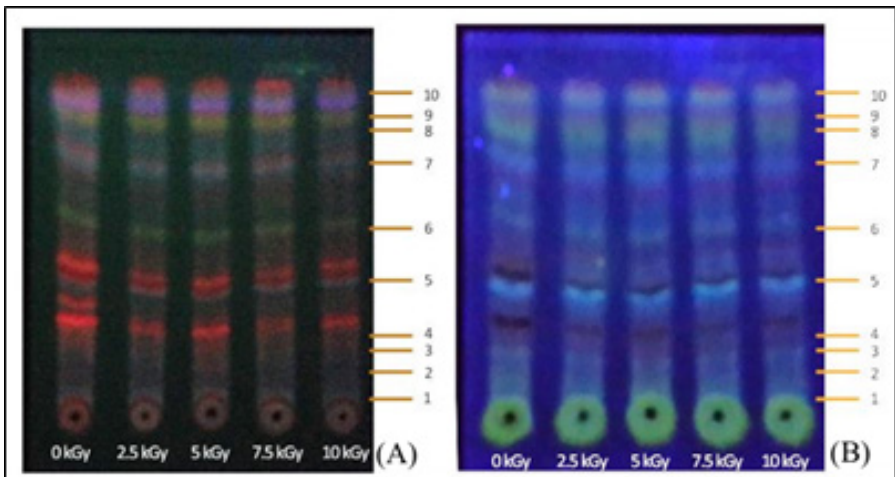

Figure 1:TLC profiles of ethanol extracts of suruhan herb powder using silica gel 60 F254 and dichloromethane: methanol (92:8) under UV light before (A) and after (B) spraying with $\mathrm{AlCl} 3$ solution.

sia. ${ }^{10} \mathrm{~A}$ previous study reported that gamma irradiation dose of 0 to 15 kGy didn't affect extraction yield of both non-irradiated and irradiated samples. ${ }^{11}$

\section{Free Radical Scavenging Assay with DPPH}

The measurement of DPPH free radical scavenging activity was based on donation of hydrogen from antioxidant to DPPH which will change the color of DPPH free radical from purple to pale yellow. ${ }^{12}$ A significant decrease of antioxidant activity at dose $10 \mathrm{kGy}$ was also reported for almond hull. ${ }^{14}$ The change of radical scavenging activity can be caused due to changes on phenolic compound because radical scavenging activity known to be correlated with phenolic acid..$^{15}$

\section{ACE Inhibitor Activity Assay}

The data obtained shows there was a decrease of ACE inhibitory activity in irradiated samples. Having the least decrease was the $2.5 \mathrm{kGy}$ irradiated sample. The different dose of irradiation may result in a difference of chemical constituents in the samples where a difference in the ACE inhibitory activity is allegedly caused by phytochemical constituents which are not exactly the same between samples. Every phytochemical has its own strength in ACE inhibition activity. ${ }^{16,17,18}$ The most significant decrease was found in the $7.5 \mathrm{kGy}$ although the decrease wasn't very far from the non-irradiated sample. Such a decrease was possible due to ionization radiation effects of irradiation which can result in chemical change caused by excitation and ionization of chemical constituents. ${ }^{19}$ Gamma irradiation may also cause electron dislocation and formation of free radicals which induces breakage of chemical bonds, therefore altering chemical structures or decomposition of phytochemicals which have an ACE inhibitory activity potential. $5,20,21$

\section{Total Phenolic Content}

The measurement of total phenolic content was done using colorimetric Folin-Ciocalteu method. A phenolic compound in alkaline will be oxidized and yields phenolate ions. The phenolate ions reduce the yellow molybdotungstophosphate heteropolyanion into blue molybdotungstophosphate, which can be measured spectrophotometrically. ${ }^{22,23}$ Based on statistical analysis using one-way ANOVA, it's known that there are no significant changes in total phenolic content for sample after irradiation at 5 and $7.5 \mathrm{kGy}$. The increase of phenolic content could be attributed to hydrolysis of glycosidic components by radical products from water radiolysis, leading to increasing of free phenolic compound. ${ }^{24}$ Meanwhile, at dose 2.5 and $10 \mathrm{kGy}$ total phenolic compound decrease significantly. The decrease of phenolic content also reported in Mucuna pruriens powder and almond hull after irradiation. ${ }^{14,25}$ The decrease of phenol content could be happened due to the interaction of radical hydroxyl from radi- 
olysis with aromatic ring on phenolic compound that caused the degradation of the aromatic ring of phenolic compound. ${ }^{27}$

\section{Total Flavonoid Content}

Total flavonoid content was measured using colorimetric method with $\mathrm{AlCl}_{3}$ and sodium acetate as reagent. $\mathrm{AlCl}_{3}$ forms acid stable complexes with keto group (C-4) and with the C-3 or C-5 hydroxyl group of flavones and flavonols. Sodium acetate detects the free hydroxyl group on C-7. ${ }^{[27]}$ Total flavonoid content after irradiated at $5 \mathrm{kGy}$ and $7.5 \mathrm{kGy}$ shows that there are no significant changes $(p>0.05)$. However, total flavonoid content significantly decreases after irradiated at 2,5 kGy and 10 kGy (Table 3). In the former study, the decrease of total flavonoid content at irradiation dose $2 \mathrm{kGy}$ and $10 \mathrm{kGy}$ was reported for almond hull powder. ${ }^{15}$ Flavonoid is one of the polyphenol groups, thus the decrease of flavonoid content could be associated with the decrease of polyphenol content.

\section{Thin Layer Chromatography (TLC) Profile}

TLC profiles of all samples under $254 \mathrm{~nm}$ and $366 \mathrm{~nm}$ were similar. The difference of amounts peaks from the non-irradiated and irradiated samples may indicate the formation of a different substance caused by irradiation..$^{28}$ Another cause is the effect of gamma irradiation which produces free radicals, therefore, inducing oxidation, hydroxylation, or degradation of components in the samples. ${ }^{29}$ Furthermore, decreasing or increasing of peak area of the irradiated samples is suggested as degradation result. ${ }^{30}$ Colour change of the spots' fluorescence after applying $\mathrm{AlCl}_{3}$ to greenish yellowish indicates the existence of flavonoids. ${ }^{31}$

\section{CONCLUSION}

Gamma irradiation of suruhan herb powder at $2.5 \mathrm{kGy}, 5 \mathrm{kGy}$, and 7.5 kGy have no significant difference in antioxidant activity compared with control. Irradiation up to $10 \mathrm{kGy}$ decreased ACE inhibitory activity of its ethanol extracts the lowest decrease was found in the $2.5 \mathrm{kGy}$ irradiated sample. Total phenolic and total flavonoid content didn't change significantly compare to the control at dose $5 \mathrm{kGy}$ and $7.5 \mathrm{kGy}$. There's a correlation between antioxidant activity with total phenolic content but not with total flavonoid content. TLC profiles of non-irradiated and irradiated samples gave similar results. Based on these findings, it is concluded that gamma irradiation can be used as a preservation method for suruhan herb powder.

\section{ACKNOWLEDGMENT}

This study supported by DRPM Universitas Indonesia via Hibah PITTA 2016.

\section{CONFLICT OF INTEREST}

None.

\section{ABBREVIATIONS USED}

ACE: Angiotensin converting enzyme; DPPH: 2,2'-Diphenyl-1-picryl hidrazyl.

\section{REFERENCES}

1. Seong Wei L, Wee W, Yong FSJ, Syamsumir D. Characterization of anticancer, antimicrobial, antioxidant properties and chemical compositions of Peperomia pellucida leaf extract. Acta Med Iran. 2011;49(10):670-4.

2. Saputri FC, Mun'im A, Lukmanto SD, Aisyah SN, Rinandy JS. Inhibition of angiotensin converting enzyme (ACE) activity by some Indonesia edible plants. Inter J Pharmaceut Scie Res. 2015;6(3):1054-9.

3. World Health Organization, The World Medicines Situation 2011. Traditional Medicines: global situatin, issues, and challenges, Geneva: World Health Organization, 2011
4. Chatterjee S, Kumar V, Khole S, Sanyal B, Murali T, Variyar P. Radiation processing: an effective quality control tool for hygienization and extending shelf life of a herbal formulation, Amritamehari churnam. J Rad Res Appl Scie. 2015:30:1-10.

5. da Silva Aquino KA. Sterilization by Gamma Radiation. In F. Adrovic (Ed.), Gamma Irradiation. 2012;171-206. Croatia: InTech.

6. Al-Saeedi $\mathrm{AH}$, Hossain MA. Total phenols, total flavonoids contents and free radical scavenging activity of seeds crude extracts of pigeon pea traditionally used in Oman for the treatment of several chronic diseases. Asian Pac J Trop Dis. 2015;5:316-21.

7. Chang C, Yang M, Wen H, Chern J. Estimation of total flavonoid content in propolis by two complementary colorimetric methods. J Food Drug Anal. 2002; 103:178-82

8. Pourmorad F, Hosseinimehr SJ, Shahabimajd N. Antioxidant activity, phenol and flavonoid contents of some selected Iranian medicinal plants. Afric J Biotechnol. 2006;5:1142-5.

9. Lestari P. Karakterisasi simplisia dan isolasi senyawa triterpenoida/steroida dari herba Suruhan (Peperomiae Pellucidae Herba), Skripsi, Medan: Fakultas Farmasi, Universitas Sumatera Utara

10. Departemen Kesehatan Republik Indonesia., Parameter Standar Umum Ekstrak Tumbuhan Obat. Jakarta: Departemen Kesehatan Republik Indonesia, 2000.

11. Katrin E, Komarudin D, Susanto, Winarno H. Pengaruh iradiasi gamma terhadap sitotoksisitas Daun Sirih Merah (Piper crocatum Ruiz \& Pav) pada Sel Leukemia L1210, Jurnal IImiah Aplikasi Isotop dan Radiasi. 2013;9(2):113-27.

12. Elya B, Dewi R, Budiman MH. Antioxidant cream of Solanum lycopersicum L, Internat J of PharmTech Res. 2013;5:233-8.

13. Byun M, Yook H, Kim K, Chung C. Effects of gamma irradiation on physiological effectiveness of Korean medicinal herbs. Rad Phys Chem. 1999;54:291-300.

14. Moosavi KS, Hosseini S, Dehghan G, Jahanban-esfahlan A. The effect of gamma irradiation on phytochemical content and antioxidant activity of stored and none stored almond (Amygdalus communis L .) hull. Pharmaceut Scie. 2014;20:102-6.

15. Antalovich M, Prenzler PD, Patsalides E, Mcdonald S, Robards K, Robards K Methods for testing antioxidant activity, Analyst. 2001;127:183-98.

16. Lacaille-Dubois MA, Franck U, Wagner H. Search for potential Angiotensin Converting Enzyme (ACE)-inhibitors from plants. Phytomed. 2001;8(1):47-52

17. Balasuriya BW, Rupasinghe HPV. Plant flavonoids as angiotensin converting enzyme inhibitors in regulation of hypertension. Funct Foods Health Dis. 2011;5:172-88.

18. Oboh G, Akinyemi AJ, Ademiluyi AO. Effect of phenolic extract from garlic on the angiotensin-1 converting enzyme and cisplatin-induced lipid peroxidation in vitro. Inter J Biomed Sci. 2013;9(2):98 -106.

19. Putri FNA, Wardani KA, Harsojo. Aplikasi teknologi iradiasi gamma dan penyimpanan beku sebagai upaya penurunan bakteri patogen pada seafood: Kajian Pustaka, Jurnal Pangan dan Agroindustri. 2015;3(2):345-52.

20. Pinela J, Barros L, Antonio AL, Carvalho AM, Oliveira MBPP, Ferriera ICFR Quality control of gamma irradiated Dwarf Mallow (Malva neglecta Wallr.) Based on color, organic acids, total phenolics and antioxidant parameters. Molecule. 2016;21(4):467-80.

21. Oms-Oliu G, Odriozola-Serrano I, Martín-Belloso O. The Effects of non-thermal Technologies on Phytochemicals. In V. Rao (Ed.), Phytochemicals - A global perspective of their role in nutrition and health. 2012; pp. 107-26. Spanyol: InTech.

22. Cicco N, Lattanzio V. The influence of initial carbonate concentration on the folinciocalteu micro-method for the determination of phenolics with low concentration in the presence of methanol: a comparative study of real-time monitored reaction. Am J Anal Chem. 2011;2:840-8

23. Cicco N, Lanorte MT, Paraggio M, Viggiano M, Lattanzio V. A reproducible, rapid and inexpenxive folin-ciocalteu micro-method in determining phenolics of plan methanol extracts Microchem . 2009:91:107-10.

24. Lee JW, Kim JK, Srinivasan P, Choi J-I, Kim JH, Han SB, Kim D-J and Byun MW. Effect of gamma irradiation on microbial analysis, antioxidant activity, sugar content and color of ready-to-use tamarind juice during storage. LWT - Food Scie Technol. 2009;42(1):101-5.

25. Bhat R, Sridhar KR, Tomita-Yokotani K. Effect of ionizing radiation on antinutritional features of velvet bean seeds (Mucuna pruriens), Food Chem. 2007:103:860-6

26. Schindler M, Solar S, Sontag G. Phenolic compounds in tomatoes, natural variations ad effect of gamma-irradiation, Eur Food Res Technol. 2005;221:439-45.

27. Markham KR. Cara mengidentifikasi flavonoid. (Kosasih P, Penerjemah), 1988, Bandung: Penerbit ITB.

28. Katrin E, Novagusuda FN, Susanto, Winarno H. Karakteristika dan khasiat daun Keladi Tikus (Typhonium divaricatum (L.) Decne) Iradiasi, Jurnal IImiah Aplikasi Isotop dan Radiasi. 2012;8(1):31-42.

29. Abdeldaiem MH, Hoda GMA, Nasr EH, Antioxidant activity of extract from gamma irradiated red grape (Vitis vinifera) seeds. J Rad Res Appl Scie. 2012;5(2):221-42.

30. Isabella E, Pohan T. Formulation of oil-in-water cream from Mangosteen (Garcinia mangostana L.) pericarp extract preserved by gamma irradiation. Atom Indonesia. 2013;39(3);136-44

31. Harborne JB. Phytochemical Methods - A guide to modern techniques of plant analysis (2nd ed.), 1984, London: Chapman and Hall.

32. Ukieyanna E. Aktivitas antioksidan, kadar fenol, dan flavonoid tumbuhan Suruhan (Peperomia pellucida L. Kunth), Bogor: Institut Pertanian Bogor, 2012 

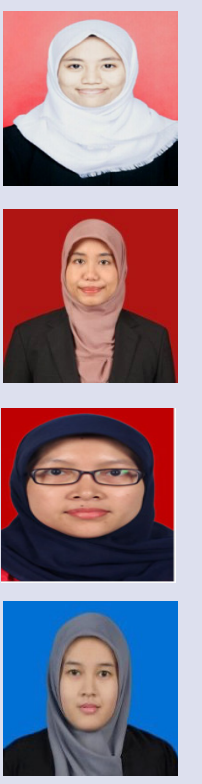

Arikadia Noviani: Is graduated from Graduate Program of Pharmacutical Scinces, Faculty of Pharmacy, Universitas Indonesia. Currently she is focusing her research in antioxidant from natural products.

Rissyelli: Is graduated in Facult of Pharmacy Universitas Indonesia. The study focused in Natural Products. Specialization course in Dyslipidemia.

Abdul Mun'im: Ph.D., Associate Professor at Department of Pharmacognosy-Phytochemistry, Faculty of Pharmacy, Universitas Indonesia (UI) Depok, West Java, Indonesia. He has experience in the area of Pharmacognosy and Phytochemistry, working in drugs discovery of herbal plants, extraction technology, Metabolite profiling, Structure Elucidation, and Degenerative Diseases (such as diabetes mellitus, antihypertension, and cholesterol)

Cite this Article: Yusuf SM, Wulandari I, Amelia L, Katrin, Noviani A, Rissyelly, Mun'im A. Effect of Gamma Irradiation on Suruhan (Peperomia pellucida (L.) Kunth) Herb Powder. Pharmacogn J. 2017;9(2):239-43. 